\title{
Gambaran Intervensi Koroner Perkutan Primer pada Pasien Infark Miokard Akut dengan Elevasi Segmen ST di RSUP Prof Dr. R. D. Kandou Manado Periode Januari -Desember 2017
}

\author{
${ }^{1}$ Cristina Lolaen \\ ${ }^{2}$ Starry H. Rampengan \\ ${ }^{2}$ Janry A. Pangemanan
}

\author{
${ }^{1}$ Program Studi Pendidikan Dokter Fakultas Kedokteran Universitas Sam Ratulangi Manado \\ ${ }^{2}$ Bagian Ilmu Penyakit Jantung dan Pembuluh Darah Fakultas Kedokteran \\ Universitas Sam Ratulangi Manado \\ Email: cristinalolaen12@gmail.com
}

\begin{abstract}
Acute coronary syndrome (ACS) is one of the main problems in the cardiovascular field due to its increasing numbers of morbidity and mortality. One of the classifications of ACS is acute myocardial infarction (AMI) with ST segment elevation (STEMI). Intervention that can be done mechanically for AMI with STEMI is primary percutaneous coronary intervention (PPCI). This study was aimed to determine the profile of PPCI in patients with AMI-STEMI at Prof. Dr. R. D. Kandou Hospital Manado from January to December 2017. This was a descriptive observational study with a retrospective approach using medical record data of AMI-STEMI patients. Samples were obtained by using consecutive sampling technique. The results showed that of the total 132 STEMI patient there were 63 samples that fulfilled the criteria. Most patients were male as many as 57 people (90.5\%), aged 45-49 years as many as 17 people (27\%), BMI 18,5-24,9 (normal) as many as 42 people $(66.6 \%)$. Of 63 samples, 24 patients had only one risk factor $(38.1 \%)$, with hypertension as the most common risk factor in 45 people (71.4\%). Among patients that underwent PPCI, the PPCI was predominantly performed on the $3-<6$ hours after onset as many as 23 people (36.5\%). Conclusion: Among patients that underwent PPCI, male patients were much more common than female, and hypertension was the most risk factor of ACS. Most PPCIs were performed on the 3-<6 hours after onset.
\end{abstract}

Keywords: AMI, STEMI, PPCI

\begin{abstract}
Abstrak: Sindrom koroner akut (SKA) merupakan salah satu masalah utama kardiovaskular karena menyebabkan tingginya angka morbiditas dan mortalitas. Salah satu klasifikasi dari SKA ialah infark miokard akut dengan elevasi segmen ST (IMA-EST). Tindakan yang dapat dilakukan secara mekanis yaitu intervensi koroner perkutan (IKP) primer. Penelitian ini bertujuan untuk mengetahui gambaran IKP primer pada pasien IMA-EST di RSUP Prof. DR. R.D. Kandou Manado periode Januari-Desember 2017. Jenis penelitian ialah deskriptif observasional dengan pendekatan retrospektif menggunakan data rekam medik pasien IMAEST. Teknik pengambilan sampel yaitu consecutive sampling. Hasil penelitian memperlihatkan dari total 132 pasien IMA-EST didapatkan 63 sampel yang memenuhi kriteria. Frekuensi terbanyak pada jenis kelamin laki-laki sebanyak 57 orang $(90,5 \%)$, kelompok usia 45-49 tahun 17 orang (27\%), IMT 18,5-24,9 (normal) 42 orang (66,6\%). Dari jumlah 63 sampel, terbanyak memiliki 1 faktor risiko yaitu 24 orang $(38,1 \%)$, dengan hipertensi sebagai faktor risiko terbanyak pada 45 orang $(71,4 \%)$. Pada pasien yang menjalani IKP primer terbanyak dilakukan pada awitan gejala $3-<6$ jam yaitu 23 orang $(36,5 \%)$. Simpulan: Pasien berjenis kelamin laki-laki paling banyak menjalani IKP primer, dengan hipertensi merupakan faktor risiko PJK terbanyak dan IKP primer terbanyak dilakukan pada awitan 3-<6 jam.
\end{abstract}

Kata kunci: IMA-EST, IPK primer 
Infark miokard akut dengan elevasi segmen ST (IMA-EST) adalah keadaan dimana aliran darah arteri koroner menurun secara mendadak setelah terjadinya oklusi trombus pada plak aterosklerosis yang memang sudah ada sebelumnya. ${ }^{1}$ Menurut European Society of Cardiology Guidelines 2017, registry IMA-EST di Swedia, tahun 2015 angka kejadiannya yaitu 58 per 100.000 per tahun. Angka kejadian di Amerika Serikat menurun yaitu dari 133 per 100.000 pada tahun 1999 menjadi 50 per 100.000 pada tahun $2008 .^{2}$ Menurut data Jakarta acute coronary syndrome registry pada bulan Oktober 2014 - Juli 2015 didapatkan total pasien sindrom koroner akut (SKA) yaitu 3.015 pasien. Pasien IMA-EST berjumlah 1.024 pasien yang di rawat di UGD rumah sakit yang berpartisipasi. Pasien yang menerima terapi reperfusi (fibrinolisis dan IKP) $54 \%$ dan yang tidak menerima terapi reperfusi $46 \%$, IKP primer adalah metode reperfusi yang paling umum dilakukan. Mortalitas di rumah sakit pada pasien yang tidak melakukan reperfusi lebih tinggi yaitu $(9,1 \%)$ dibandingkan dengan pasien yang menerima IKP primer $(3,2 \%)$ atau terapi fibrinolitik $(3,8 \%){ }^{3}$

Faktor risiko yang dapat menyebabkan terjadinya infark miokard (IM) terbagi menjadi dua yaitu yang dapat dimodifikasi (hipertensi, diabetes melitus, merokok, dislipidemia, obesitas) dan faktor risiko yang tidak dapat dimodifikasi (usia, jenis kelamin, riwayat penyakit jantung sebelumnya dan riwayat keluarga). ${ }^{4-10}$

Diagnosis harus ditegakkan berdasarkan anamnesis yang cermat, yaitu ditanyakan awitan nyeri dada, durasi, sifat dan apakah menyebar atau tidak. Pada pemeriksaan fisik bisa didapatkan penampilan umum pasien yaitu gelisah, cemas kemudian dingin dan ekstremitas lembab. Pada pemeriksaan penunjang yang dapat dilakukan yaitu EKG 12 sadapan, harus dilakukan segera dalam 10 menit sejak kedatangan pasien di UGD. Juga dapat dilakukan pemeriksaan petanda (biomarker) kerusakan jantung, yang dianjurkan yaitu CKMB dan Troponin I atau T. ${ }^{1,11,12}$

Penatalaksanaan yang dapat dilakukan pada pasien yang didiagnosis dengan STEMI yaitu terapi reperfusi, salah satunya yaitu intervensi koroner perkutan primer. Intervensi koroner perkutan primer adalah intervensi dengan balloon, stent, atau alat lainnya yang dilakukan pada arteri yang infark (infarct-related artery/IRA) dengan awitan 12 jam sejak timbulnya gejala nyeri dada atau gejala lainnya, tanpa terapi fibrinolitik sebelumnya. ${ }^{2,11}$

Penelitian ini bertujuan untuk mengetahui gambaran intervensi koroner perkutan primer pada pasien infark miokard akut dengan elevasi segmen ST (IMA-EST) di RSUP Prof. Dr. R. D. Kandou Manado periode Januari - Desember 2017.

\section{METODE PENELITIAN}

Jenis penelitian ini yaitu deskriptif observasional dengan pendekatan retrospektif menggunakan data sekunder dari data rekam medik pasien infark miokard akut dengan elevasi segmen ST (IMA-EST) yang menjalani intervensi koroner perkutan (IKP) primer di RSUP Prof. Dr. R. D. Kandou Manado periode Januari - Desember 2017. Pada penelitian ini didapatkan 132 pasien yang didiagnosis dengan IMAEST dan yang memenuhi kriteria inklusi yaitu yang menjalani terapi IKP primer berjumlah 63 orang. Pengelolan data dilakukan secara manual dan komputerisasi.

\section{HASIL PENELITIAN}

Pada penelitian ini didapatkan total pasien yang didiagnosis dengan pasien IMA-EST sebanyak 132 pasien periode Januari - Desember 2017. Yang memenuhi kriteria inklusi berjumlah 63 orang. Terdapat 69 pasien dieksklusi, yaitu 24 pasien tidak melakukan terapi reperfusi, 5 pasien dilakukan terapi fibrinolitik, 3 pasien menjalani rescue percutaneous coronary intervention, 29 pasien memiliki awitan gejala $>12$ jam kemudian menjalani intervensi koroner perkutan, 7 pasien memiliki data tidak lengkap yaitu tidak ada data mengenai awitan terjadinya nyeri dada, dan 1 pasien gagal dilakukan tindakan IKP primer karena pasien meninggal. 
Dari hasil penelitian didapatkan pasien yang didiagnosis dengan IMA-EST dan dirawat tahun 2017, laki-laki sebanyak 113 orang $(85,6 \%)$ dan perempuan sebanyak 19 orang $(14,4 \%)$ (Tabel 1). Pasien yang menjalani IKP primer, laki-laki sebanyak 57 orang $(90,5 \%)$ dan perempuan sebanyak 6 orang $(9,5 \%)$ (Tabel 2).

Tabel 1. Distribusi pasien IMA-EST yang dirawat pada tahun 2017

\begin{tabular}{ccc}
\hline $\begin{array}{c}\text { Jenis } \\
\text { kelamin }\end{array}$ & $\begin{array}{c}\text { Jumlah } \\
(\mathbf{n})\end{array}$ & $\begin{array}{c}\text { Persentase } \\
(\mathbf{\%})\end{array}$ \\
\hline Perempuan & 19 & 14,4 \\
Laki-laki & 113 & 85,6 \\
Jumlah & 132 & 100 \\
\hline
\end{tabular}

Tabel 2. Distribusi pasien yang menjalani IKP primer berdasarkan jenis kelamin.

\begin{tabular}{ccc}
\hline $\begin{array}{c}\text { Jenis } \\
\text { kelamin }\end{array}$ & $\begin{array}{c}\text { Jumlah } \\
(\mathbf{n})\end{array}$ & $\begin{array}{c}\text { Persentase } \\
(\boldsymbol{\%})\end{array}$ \\
\hline Perempuan & 6 & 9,5 \\
Laki-laki & 57 & 90,5 \\
\hline Jumlah & 63 & 100 \\
\hline
\end{tabular}

Berdasarkan kelompok usia, terbanyak pada usia 45-49 tahun yaitu sebanyak 17 orang (27\%), kemudian diikuti usia 50-54 tahun sebanyak 10 orang $(15,9 \%)$, usia 65 69 tahun sebanyak 8 orang $(12,7 \%)$, usia 55-59 tahun sebanyak 6 orang $(9,5 \%)$, usia 60-64 tahun sebanyak 6 orang $(9,5 \%)$, usia 40-44 tahun sebanyak 5 orang $(7,9 \%)$, begitu juga dengan usia $\geq 75$ tahun sebanyak 5 orang (7,9\%), usia 34-39 tahun sebanyak 3 orang $(4,8 \%)$, usia $70-74$ tahun juga sebanyak 3 orang $(4,8 \%)$ (Tabel 3$)$.

Dari hasil penelitian didapatkan paling banyak memiliki indeks massa tubuh (IMT) di rentang 18,5-24,9 yaitu berjumlah 42 orang $(66,6 \%)$, diikuti dengan IMT 25-29,9 yaitu berjumlah 16 orang $(25,4 \%)$, IMT $30-$ 34,9 berjumlah 3 orang $(4,8 \%)$, IMT $>40$, dan IMT <18,5 masing-masing berjumlah 1 orang $(1,6 \%)$ dan $(1,6 \%)$ (Tabel 4).

Dari hasil penelitian didapatkan pasien yang memiliki faktor risiko hipertensi berjumlah 45 orang $(71,4 \%)$, dan yang tidak memiliki faktor risiko hipertensi berjumlah 18 orang $(28,6 \%)$ (Tabel 5).
Tabel 3. Distribusi pasien yang menjalani IKP primer berdasarkan usia.

\begin{tabular}{ccc}
\hline $\begin{array}{c}\text { Usia } \\
\text { (tahun) }\end{array}$ & $\begin{array}{c}\text { Jumlah } \\
(\mathbf{n})\end{array}$ & $\begin{array}{c}\text { Persentase } \\
(\%)\end{array}$ \\
\hline $34-39$ & 3 & 4,8 \\
$40-44$ & 5 & 7,9 \\
$45-49$ & 17 & 27 \\
$50-54$ & 10 & 15,9 \\
$55-59$ & 6 & 9,5 \\
$60-64$ & 6 & 9,5 \\
$65-69$ & 8 & 12, \\
$70-74$ & 3 & 4, \\
$\geq 75$ & 5 & 7,9 \\
Jumlah & 63 & 10 \\
\hline
\end{tabular}

Tabel 4. Distribusi pasien yang menjalani IKP primer berdasarkan indeks massa tubuh

\begin{tabular}{ccc}
\hline IMT & $\begin{array}{c}\text { Jumlah } \\
(\mathbf{n})\end{array}$ & $\begin{array}{c}\text { Persentase } \\
(\mathbf{\%})\end{array}$ \\
\hline$<18,5$ & 1 & 1,6 \\
$18,5-24,9$ & 42 & 66,6 \\
$25-29,9$ & 16 & 25,4 \\
$30-34,9$ & 3 & 4,8 \\
$35-39,9$ & 0 & 0 \\
$>40$ & 1 & 1,6 \\
Jumlah & 63 & 100 \\
\hline
\end{tabular}

Tabel 5. Distribusi pasien yang menjalani IKP primer berdasarkan faktor risiko hipertensi

\begin{tabular}{ccc}
\hline Hipertensi & $\begin{array}{c}\text { Jumlah } \\
(\mathbf{n})\end{array}$ & $\begin{array}{c}\text { Persentase } \\
(\boldsymbol{\%})\end{array}$ \\
\hline Ya & 45 & 71,4 \\
Tidak & 18 & 28,6 \\
Jumlah & 63 & 100 \\
\hline
\end{tabular}

Dari hasil penelitian didapatkan bahwa pasien yang memiliki faktor risiko diabetes melitus (DM) berjumlah 11 orang $(17,5 \%)$ dan yang tidak memiliki faktor risiko DM berjumlah 52 orang $(82,5 \%)$ (Tabel 6).

Dari hasil penelitian didapatkan bahwa pasien yang merokok berjumlah 34 orang (54\%) dan yang tidak merokok berjumlah 29 orang (46\%) (Tabel 7).

Dari hasil penelitian didapatkan pasien yang memiliki faktor risiko dislipidemia berjumlah 20 orang $(31,7 \%)$ dan yang tidak memilki faktor risiko dislipidemia berjumlah 43 orang $(68,3 \%)$ (Tabel 8). 
Tabel 6. Distribusi pasien yang menjalani IKP primer berdasarkan faktor risiko diabetes melitus

\begin{tabular}{ccc}
\hline $\begin{array}{c}\text { Diabetes } \\
\text { melitus }\end{array}$ & $\begin{array}{c}\text { Jumlah } \\
(\mathbf{n})\end{array}$ & $\begin{array}{c}\text { Persentase } \\
(\boldsymbol{\%})\end{array}$ \\
\hline Ya & 11 & 17,5 \\
Tidak & 52 & 82,5 \\
Jumlah & 63 & 100 \\
\hline
\end{tabular}

Tabel 7. Distribusi pasien yang menjalani IKP primer berdasarkan faktor risiko merokok

\begin{tabular}{ccc}
\hline Merokok & $\begin{array}{c}\text { Jumlah } \\
(\mathbf{n})\end{array}$ & $\begin{array}{c}\text { Persentase } \\
(\boldsymbol{\%})\end{array}$ \\
\hline Ya & 34 & 54 \\
Tidak & 29 & 46 \\
Jumlah & 63 & 100 \\
\hline
\end{tabular}

Tabel 8. Distribusi pasien yang menjalani IKP primer berdasarkan faktor risiko dislipidemia

\begin{tabular}{ccc}
\hline Dislipidemia & $\begin{array}{c}\text { Jumlah } \\
(\mathbf{n})\end{array}$ & $\begin{array}{c}\text { Persentase } \\
(\boldsymbol{\%})\end{array}$ \\
\hline Ya & 20 & 31,7 \\
Tidak & 43 & 68,3 \\
Jumlah & 63 & 100 \\
\hline
\end{tabular}

Dari hasil penelitian didapatkan bahwa pasien yang memiliki faktor risiko obesitas berjumlah 4 orang $(6,3 \%)$ dan 59 orang tidak memiliki faktor risiko obesitas $(93,7 \%)$ (Tabel 9).

Tabel 9. Distribusi pasien yang menjalani IKP primer berdasarkan faktor risiko obesitas

\begin{tabular}{ccc}
\hline Obesitas & $\begin{array}{c}\text { Jumlah } \\
(\mathbf{n})\end{array}$ & $\begin{array}{c}\text { Persentase } \\
(\boldsymbol{\%})\end{array}$ \\
\hline Ya & 4 & 6,3 \\
Tidak & 59 & 93,7 \\
Jumlah & 3 & 100 \\
\hline
\end{tabular}

Dari hasil penelitian didapatkan bahwa pasien yang memiliki riwayat penyakit jantung sebelumnya berjumlah 4 orang $(6,3 \%)$ dan yang tidak memiliki penyakit jantung sebelumnya berjumlah 59 orang $(93,7 \%)$ (Tabel 10).

Dari hasil penelitian didapatkan bahwa pasien yang memiliki riwayat penyakit jantung pada keluarga yaitu 1 orang $(1,6 \%)$ dan yang tidak memiliki riwayat penyakit jantung pada keluarga berjumlah 62 orang $(98,4 \%)$ (Tabel 11).

Tabel 10. Distribusi pasien yang menjalani IKP primer berdasarkan faktor risiko riwayat penyakit jantung sebelumnya

\begin{tabular}{ccc}
\hline $\begin{array}{c}\text { Riwayat penyakit } \\
\text { jantung sebelumnya }\end{array}$ & $\begin{array}{c}\text { Jumlah } \\
(\mathbf{n})\end{array}$ & $\begin{array}{c}\text { Persentase } \\
(\mathbf{\%})\end{array}$ \\
\hline Ya & 4 & 6,3 \\
Tidak & 59 & 93,7 \\
Jumlah & 63 & 100 \\
\hline
\end{tabular}

Tabel 11. Distribusi pasien yang menjalani IKP primer berdasarkan faktor risiko riwayat penyakit keluarga

\begin{tabular}{ccc}
\hline $\begin{array}{c}\text { Riwayat penyakit } \\
\text { keluarga }\end{array}$ & $\begin{array}{c}\text { Jumlah } \\
(\mathbf{n})\end{array}$ & $\begin{array}{c}\text { Persentase } \\
(\mathbf{\%})\end{array}$ \\
\hline Ya & 1 & 1,6 \\
Tidak & 62 & 98,4 \\
Jumlah & 63 & 100 \\
\hline
\end{tabular}

Dari hasil penelitan didapatkan bahwa pasien yang didiagnosis dengan IMA-EST paling banyak yaitu memiliki jumlah faktor risiko 1 faktor risiko saja yaitu berjumlah 24 orang $(38,1 \%)$, kemudian diikuti oleh jumlah 2 faktor risiko 22 orang (34,9\%), pasien dengan 3 faktor risiko berjumlah 14 orang $(22,2 \%)$, pasien dengan 4 faktor risiko 1 orang $(1,6 \%)$ dan pasien yang tidak memiliki faktor risiko 2 orang $(3,2 \%)$ (Tabel 12).

Tabel 12. Distribusi pasien yang menjalani IKP primer berdasarkan jumlah faktor risiko

\begin{tabular}{ccc}
\hline $\begin{array}{c}\text { Jumlah faktor } \\
\text { risiko }\end{array}$ & (n) & $\begin{array}{c}\text { Persentase } \\
(\%)\end{array}$ \\
\hline Tidak ada & & \\
faktor risiko & 2 & 3,2 \\
1 & 24 & 38,1 \\
2 & 22 & 34,9 \\
3 & 14 & 22,2 \\
4 & 1 & 1,6 \\
Jumlah & 63 & 100 \\
\hline
\end{tabular}

Dari hasil penelitian didapatkan bahwa pasien yang didiagnosis dengan IMA-EST dan menjalani intervensi koroner perkutan primer terbanyak yaitu pada awitan 3-<6 jam yang berjumlah 23 orang $(36,5 \%)$ 
diikuti oleh awitan 0-<3 jam berjumlah 15 orang $(23,8 \%)$, awitan $6-<9 \mathrm{jm}$ berjumlah 15 orang $(23,8 \%)$, dan awitan 9-12 jam berjumlah 10 orang $(15,9 \%)$ (Tabel 13).

Tabel 13. Distribusi pasien yang menjalani IKP primer berdasarkan awitan gejala

\begin{tabular}{ccc}
\hline $\begin{array}{c}\text { Awitan } \\
\text { gejala }\end{array}$ & $\begin{array}{c}\text { Jumlah } \\
(\mathbf{n})\end{array}$ & $\begin{array}{c}\text { Persentase } \\
(\boldsymbol{\%})\end{array}$ \\
\hline $0-<3$ jam & 15 & 23,8 \\
$3-<6$ jam & 23 & 36,5 \\
$6-<9$ jam & 15 & 23,8 \\
$9-12$ jam & 10 & 15,9 \\
Jumlah & 63 & 100 \\
\hline
\end{tabular}

\section{BAHASAN}

Berdasarkan hasil penelitian didapatkan bahwa pasien yang didiagnosis dengan (IMA-EST) dan menjalani IKP primer, terbanyak pada jenis kelamin laki-laki. Hasil penelitian ini selaras dengan penelitian yang dilaporkan oleh Muhammad dan Ardiantho ${ }^{9}$ yang dilakukan di RSUP DR Kariadi Semarang, yaitu dari 188 orang sampel penelitian, yang didiagnosis dengan IMA-EST, paling banyak terdapat pada pasien berjenis kelamin laki-laki berjumlah 126 orang dan perempuan hanya berjumlah 62 orang. Hal yang serupa juga dilaporkan oleh Nugroho ${ }^{13}$ di RSUD Dr. Moewardi yaitu dari jumlah sampel 54 orang, terdapat 27 orang yang didiagnosis dengan IMAEST, paling banyak pasien berjenis kelamin laki-laki yaitu berjumlah 20 orang dibandingkan dengan jenis kelamin perempuan yang hanya berjumlah 7 orang.

Berdasarkan distribusi usia, pada penelitian ini didapatkan terbanyak pada usia 45-49 tahun yang berjumlah 17 orang (27\%), diikuti kelompok usia 50-54 tahun berjumlah 10 orang $(15,9 \%)$. Hasil penelitian ini sejalan dengan penelitian yang dilaporkan oleh Putra et al $^{14}$ dilakukan di bangsal jantung RSUP Dr. M Djamil Padang, yaitu dari jumlah sampel 181 orang, didapatkan pasien yang didiagnosis dengan IMA-EST tertinggi pada usia 45-54 tahun yaitu berjumlah 70 orang. Hasil penelitian ini tidak sejalan dengan penelitian yang dilakukan oleh Edward et $\mathrm{al}^{15}$ yang melaporkan dari total sampel 83 orang yang didiagnosis IMA-EST didapatkan tertinggi pada usia 60-69 tahun. Hal ini dapat disebabkan oleh karena elastisitas pembuluh darah yang akan semakin menurun seiring dengan bertambahnya usia seseorang dan adanya faktor risiko lain yang memicu terjadinya infark miokard. ${ }^{15}$ Kerentanan terjadinya aterosklerosis koroner meningkat seiring bertambahnya usia namun jarang timbul sebelum usia 40 tahun, sedangkan dari usia 40-60 tahun insiden miokard infark meningkat lima kali lipat. ${ }^{4,5}$ Hasil yang didapatkan oleh peneliti ialah sebelum usia 40 tahun hanya tedapat 3 kasus, sedangkan pada usia 40 sampai sebelum usia 60 tahun, didapatkan 38 kasus.

Berdasarkan distribusi sampel menurut IMT pasien yang didiagnosis dengan IMA-EST didapatkan bahwa paling banyak pasien yang memiliki IMT 18,5-24,9 (normal), berjumlah 42 orang $(66,6 \%)$, diikuti oleh IMT 25-29,9 (preobese) sebanyak 10 orang $(25,4 \%)$, IMT 30-34,9 (Obese I) berjumlah 3 orang $(4,8 \%)$, IMT $>40$ (Obese III) berjumlah 1 orang $(1,6 \%$ ). Jadi dari penelitian ini didapatkan bahwa pasien yang obes berjumlah 4 orang $(6,3 \%)$. Obesitas meningkatkan risiko terkena PJK. Sekitar 25-49\% PJK di negara berkembang berhubungan dengan adanya peningkatan pada IMT yang overweight dengan IMT $>25-30 \mathrm{~kg} / \mathrm{m}^{2}$ dan obesitas dengan IMT $>30 \mathrm{~kg} / \mathrm{m}^{2}$.

Berdasarkan distribusi sampel, pasien yang didiagnosis dengan IMA-EST yang memiliki faktor risiko hipertensi berjumlah 45 orang $(71,4 \%)$, dan yang tidak memiliki faktor risiko hipertensi berjumlah 18 orang $(28,6 \%)$. Hasil penelitian ini sejalan dengan penelitian yang dilaporkan oleh Budiman, et $\mathrm{al}^{16}$ yang dilakukan di RSUD 45 Kuningan yaitu dari jumlah 71 orang yang didiagnosis dengan IMA, paling banyak pasien memiliki faktor risiko hipertensi yaitu berjumlah 41 orang dibandingkan dengan yang tidak memiliki faktor risiko hipertensi yaitu berjumlah 30 orang. Namun karena penelitian yang dilakukan oleh peneliti bersifat retrospektif, hanya 
melihat data pasien dari rekam medik, tidak menanyakan langsung pada pasien, sehingga peneliti tidak bisa mendapatkan data secara lebih detail. Pada saat terjadi peningkatan tekanan darah sistemik, hal ini akan meningkatkan resistensi terhadap pemompaan darah dari ventrikel kiri, sehingga beban jantung bertambah, akibatnya terjadi hipertrofi ventrikel untuk meningkatkan kekuatan kontraksi. Kemampuan ventrikel untuk mempertahankan curah jantung dengan hipertrofi kompensasi akhirnya terlampaui, dan terjadi dilatasi dan payah jantung. ${ }^{6}$ Hipertensi juga dapat menimbulkan trauma langsung terhadap dinding pembuluh darah arteri koronaria, sehingga memudahkan terjadinya aterosklerosis koroner. Hipertensi merupakan faktor risiko penting untuk aterosklerosis, akan terjadi pengurangan diameter lumen arteri koroner oleh plak atheromatous bila proses aterosklerosis ini berlanjut, akhirnya mengurangi aliran darah miokardium, dengan demikian terjadi iskemia. Plak-plak ini akhirnya bisa pecah, selanjunya akan membentuk emboli perifer atau terutama trombus in situ dengan cara agregasi trombosit yang bertanggung jawab untuk SKA. Pada keadaan hipertensi tidak hanya terjadi pembentukan aterosklerosis yang pada suatu keadaan nanti dapat pecah, tapi juga dikaitkan dengan terjadinya anomali mikrosirkulasi koroner yaitu adanya fibrosis peri-vaskular, dan juga adanya penebalan tunika intima. Hal ini yang kemudian menyebabkan terjadinya infark miokard, lebih sering didapatkan pada penyandang hipertensi dibandingkan dengan yang memiliki tekanan darah normal. ${ }^{17,18}$

Hipertensi merupakan suatu penyakit multifaktor yang bisa timbul karena interaksi faktor-faktor risiko tertentu antara lain faktor genetik. Pada pasien yang memiliki keluarga dengan hipertensi maka dapat menyebabkan adanya kelainan pada arteriol perifer mereka (pembuluh arteri kecil yang memasok darah ke jaringan tubuh). Abnormalitas genetik itu menyebabkan dinding pembuluh darah menjadi kaku sehingga terdapat tahanan yang besar ketika darah mengalir di dalamnya. Bisa juga karena asupan garam, stres emosional, serta kebisaan merokok dan konsumsi alkohol. Usia juga dapat memengaruhi karena seiring bertambahnya usia, akan terjadi penurunan fungsi organ hemodinamik tubuh dan juga berkurangnya elastisitas dinding pembuluh darah. Hal itu mengakibatkan peningkatan tahanan pembuluh darah kapiler sehingga dapat mencetuskan terjadinya kenaikan tekanan darah. Jika berlangsung cukup lama maka kenaikan tekanan darah ini akan berakhir pada keadaan hipertensi. ${ }^{19}$

Berdasarkan distrisbusi sampel, pasien IMA-EST yang memiliki faktor risiko DM berjumlah 11 orang $(17,5 \%)$, dan yang tidak memiliki faktor risiko DMberjumlah 52 orang $(82,5 \%)$. Hasil ini berbeda dengan penelitian yang dilaporkan oleh Vinod et $\mathrm{al}^{20}$ di Rumah Sakit Kolkata, Benggala Barat, dimana didapatkan dari 100 sampel penelitian terdapat 67 orang yang didiagnosis dengan IMA-EST dan dari 67 orang tersebut terdapat 49 orang yang memiliki DM. Penyandang DM cenderung memiliki prevelensi, prematuritas, dan keparahan aterosklerosis koroner yang lebih tinggi. ${ }^{6}$

Berdasarkan distribusi sampel, pasien IMA-EST yang merokok bejumlah 34 orang (54\%), dan yang tidak merokok 29 orang $(46 \%)$. Hasil penelitian ini sejalan dengan penelitian yang dilaporkan oleh Putra et al $^{14}$ di bangsal jantung RSUP Dr. M. Djamil Padang bahwa pada pasien yang didiagnosis dengan IMA-EST dari jumlah sampel 181 orang, terdapat 122 orang yang merokok. Jadi pada pasien IMA-EST terdapat lebih banyak pasien yang merokok dibandingkan yang tidak merokok. Kandungan nikotin di dalam rokok dapat menganggu sistem saraf simpatis dengan akibat dapat meningkatkan kebutuhan oksigen miokard. ${ }^{6}$

Berdasarkan distribusi pasien IMAEST, didapatkan pasien yang memiliki faktor risiko dislipidemia berjumlah 20 orang $(31,7 \%)$ dan yang tidak memiliki faktor risiko dislipidemia berjumlah 43 orang $(68,3 \%)$. Hasil penelitian ini sejalan dengan penelitian oleh Rosmiatin ${ }^{21}$ yang 
dilakukan di RSUPN Dr. Cipto Mangunkusumo Jakarta yang melaporkan bahwa pada PJK sebagian besar pasien tidak memiliki dislipidemia. Dari jumlah sampel 78 orang, pasien yang memiliki dislipidemia berjumlah 29 orang dan 49 orang tidak memiliki faktor risiko dislipidemia. Pada proses terganggunya profil lipid dalam darah terjadi penimbunan lemak di lapisan pembuluh darah yang akhirnya mengurangi diameter lumen pembuluh darah, akibatnya akan terjadi iskemia, dengan manifestasi lanjutannya ialah terjadi infark. ${ }^{10}$

Berdasarkan distribusi sampel, pasien IMA-EST didapatkan, yang memiliki riwayat penyakit jantung sebelumnya berjumlah 4 orang $(6,3 \%)$, dan yang tidak memiliki riwayat penyakit jantung sebelumnya berjumlah 59 orang $(93,7 \%)$. Yang memiliki riwayat penyakit jantung pada keluarga berjumlah 1 orang $(1,6 \%)$, dan yang tidak memiliki riwayat penyakit jantung pada keluarga berjumlah 62 orang $(98,4 \%)$. Hasil peneliltian ini sejalan dengan penelitian yang dilaporkan oleh Stivano et $\mathrm{al}^{22}$ yang dilakukan di RSU Bethesda Tomohon, dimana riwayat penyakit jantung pada keluarga hanya dimiliki oleh 1 orang saja dari jumlah 37 orang penderita SKA yang menjadi sampel. Pada pasien yang memiliki riwayat penyakit jantung sebelumnya, proses IMA-EST biasanya berkembang dengan adanya pembentukan trombus oklusif (gumpalan darah) di dalam arteri koroner utama, yang memang sebelumnya telah mengalami aterosklerosis. Pada pasien yang memiliki riwayat penyakit jantung dalam keluarganya, baik saudara laki-laki atau orang tua penderita yang mengalami PJK sebelum usia 50 tahun, meningkatkan kemungkinan timbulnya aterosklerosis prematur. Pada seseorang yang memiliki keturunan PJK prematur dapat terjadi perubahan dalam penanda aterosklerosis awal, misal reaktivitas arteri brakialis dan peningkatan dari tunika intima arteri karotis dan adanya penebalan tunika media. Adanya hipertensi, dan peningkatan lipid, ditemukan pada individu tersebut. Penelitian yang didapatkan ini sangat mengesankan bahwa adanya riwayat dalam keluarga mencerminkan suatu predisposisi genetik terhadap dis-fungsi endotel dalam arteria koronaria. 6,7

Dari hasil penelitian, didapatkan bahwa paling banyak pasien yang didiagnosis dengan IMA-EST memiliki 1 faktor risiko yaitu berjumlah 24 orang $(38,1 \%)$ diikuti dengan pasien yang memiliki 2 faktor risiko berjumlah 22 orang $(34,9 \%)$ pasien yang memiliki 3 faktor risiko berjumlah 14 orang $(22,2 \%)$, pasien yang memiliki 4 faktor risiko 1 orang $(1,6 \%)$. Dari data yang didapatkan, 2 orang pasien yang tidak memiliki faktor risiko. Hasil ini sejalan dengan penelitian yang dilakukan oleh Putra et $\mathrm{al}^{14}$ yaitu dari 181 sampel, didapatkan 99 orang memiliki kurang dari 3 faktor risiko dan 82 orang memiliki lebih dari 3 faktor risiko.

Berdasarkan distribusi sampel diperoleh bahwa pasien yang didiagnosis dengan IMA-EST dan menjalani IKP primer, yaitu awitan gejala didapatkan terbayak pada awitan 3-<6 jam berjumlah 23 orang (36,5\%), awitan $0-<3$ jam 15 orang $(23,8 \%)$, awitan 6-<9 jam 15 orang $(23,8 \%)$, dan awitan 9-12 jam 10 orang $(15,9 \%)$. Strategi pengobatan IMA-EST sangat berkaitan dengan masa awitan (time onset) dari gejala nyeri dada demi mendapatkan tatalaksana yang tepat dan cepat. Salah satu tindakan yang dilakukan yaitu tindakan IKP primer, dengan tujuan pengobatan utama yaitu untuk secara cepat membuka arteri yang tersumbat. ${ }^{23}$ Intervensi koroner perkutan primer itu adalah strategi reperfusi yang dilakukan pada pasien IMA-EST dengan awitan serangan yaitu 12 jam sejak timbulnya gejala. Dari hasil penelitian, tindakan IKP primer paling tinggi dilakukan pada pasien dengan awitan gejala $3-<6$ jam.

\section{SIMPULAN}

Berdasarkan hasil penelitian ini dapat disimpulkan bahwa pasien yang terbanyak menjalani IKP primer berjenis kelamin laki-laki, usia 45-49 tahun, IMT 18,5-24,9 (normal), dengan satu faktor risiko. IKP primer terbanyak dilakukan pada awitan 3$<6$ jam sejak timbulnya gejala nyeri dada. 


\section{SARAN}

Untuk penelitian selanjutnya, diharapkan dapat menggunakan rentang waktu yang lebih panjang dan jumlah sampel yang lebih besar, agar bisa mendapatkan hasil penelitian yang maksimal dan memuaskan.

Diharapkan data rekam medik kedepannya akan lebih teratur, lebih lengkap dan lebih diperjelas pemgisiannya agar dapat menunjang penelitian yang akan dilakukan dan memperoleh hasil yang lebih baik dan lebih akurat.

\section{DAFTAR PUSTAKA}

1. Alwi I. Infark miokard akut dengan elevasi segmen ST. In: Sudoyo AW, Setiyohadi B, Alwi I, Simadibrata M, Setiati S, editors. Buku Ajar Ilmu Penyakit Dalam Jilid II (5th ed). Jakarta: Interna Publishing, 2010; p. 1741-54.

2. Ibanez B, James S, Agewall S, Antunes MJ, Bucciarelli-Ducci $\mathrm{C}$, Bueno $\mathrm{H}$, et al. 2017 ESC Guidelines for the management of acute myocardial infarction in patients presenting with ST-segment elevation. Eur Heart J. 2018;39(2):119-77.

3. Dharma S, Andriantoro H, Purnawan I, Dakota I, Basalamah F, Hartono B, et al. Characteristics, treatment and inhospital outcomes of patients with STEMI in a metropolitan area of a developing country: an initial report of the extended Jakarta Acute Coronary Syndrome registry. BMJ Open. 2016; 6(8):e012193.

4. Kumar V, Abbas AK, Aster JC. Buku Ajar Patologi Robbins Volume 2 (9th ed). Singapura: Elsevier, 2015; p. 377-84.

5. Boudi BF. Risk factor for coronary artery disease (medscape). Cardiology. 2016. Available from: https://emedicine. medscape.com/article/164163overview.

6. Price S. Patofisiologi Konsep Klinis ProsesProses Penyakit Vol 1 (6th ed). Jakarta: EGC, 2005; p. 579-85.

7. Dewi RF, Wahid A, Hafifah I. Gambaran faktor risiko pada kejadian mortalitas pasien stemi di RSUD ULIN Banjarmasin. Dunia Keperawatan. 2016; 4(2):110-4.
8. Alamira Sofyan, Itsaini. Perbandingan clinical outcome pasien infark miokard akut ST-elevasi (STEMI) pasca terapi intervensi koroner perkutan primer dan terapi fibrinolitik di RSUP Dr. Kariadi Semarang. Semarang: Universitas Muhammadiyah; 2016.

9. Muhammad GR, Ardhianto P. Profil Faktor Risiko Atherosklerosis Pada Kejadian Infark Miokard Akut Dengan StSegment Elevasi Di Rsup Dr Kariadi Semarang. Media Med Muda. 2015;4(4):849-58.

10. Budiman, Sihombing $R$, Pradina $P$. Hubungan dislipidemia, hipertensi dan diabetes melitus dengan kejadian infark miokard akut. JKMA. 2015;10(1):327.

11. Juzar DA, Danny SS, Irmalita, et al. Pedoman tatalaksana sindrom koroner akut (4th ed). Jakarta: Perhimpunan Dokter Spesialis Kardiovaskular Indonesia, 2018; p. 1-13, 44-73.

12. Rampengan SH. Kegawatdaruratan Jantung. Jakarta: FKUI; 2015. h. 1-52.

13. Nugroho IS. Perbedaan kadar SGOT pada pasien ST-elevasi miokard infark (STEMI) dan non-ST elevasi infark miokard (NSTEMI) di RSUP Dr. Moewardi. Surakarta: Universitas Muhammadiyah Surakarta; 2018.

14. Putra S, Eka FE, Afdai. Gambaran faktor risiko dan managemen reperfusi pasien IMA-EST di bangsal jantung RSUP Dr. M Djamil Padang. Jurnal Kesehatan Andalas. 2017;6(3):579-80.

15. 15Wagyu EA, Rampengan SH, Pangemanan JA. Gambaran pasien infark miokard dengan elevasi segmen ST (STEMI) yang dirawat di BLU Prof Dr. R. D. Kandou Manado Periode Januari sampai Desember 2010. eCl. 2013;1(3).

16. Budiman, Rosmariana S, Paramita $P$. Hubungan dislipidemia, hipertensi dan diabetes melitus dengan kejadian infark miokard akut. Jurnal FKM Universitas Andalas. 2015;10(1)L32-7.

17. European society of hypertension scientific news: update on hypertension management. 2005; p. 6.

18. Djohan TBA. Penyakit jantung koroner dan hipertensi. e-USU, 2004; p. 1-7. Available from: library.USU.ac.id/ download/fk/gizi-bahri10.pdf.

19. Dwiputra B. Hubungan perilaku dengan 
prevalensi hipertensi pada masyarakat Kota Ternate tahun 2008 [Skripsi]. Jakarta: Fakultas Kedokteran Universitas Indonesia; 2009.

20. Vinod WC, Tapas R, Chandramouli B, Abhinav DW. Clinical profile of patients with acute coronary syndrome with special reference to diabetes mellitus. IJRMS. 2015; 3(4):853.

21. Rosmiatin M. Analisis faktor-faktor risiko terhadap kejadian penyakit jantung koroner pada wanita lanjut usia di RSUPN Dr. Cipto Mangunkusumo. Depok: Fakultas Kedokteram Universitas Indonesia; 2012.

22. Stivano VT, Panda AL, Ongkowijoyo J. Gambaran faktor risiko sindrom koroner akut. eCl. 2014;2(1);8.

23. Prasetya A. Peguatan rantai survival pasien stemi. Medical Majapahit. 2017;9(1): 2. 